\title{
EFFICACY AND OUTCOMES OF HEARING PRESERVATION TECHNIQUE IN COCHLEAR IMPLANTEES WITH RESIDUAL HEARING: EXPERIENCE IN INDIAN PATIENTS
}

\author{
Ashish Alappatt ${ }^{1}$, Vijaya Krishnan Paramasivan², Senthil Vadivu Arumugam¹, \\ Raghunandhan Sampath², Mohan Kameswaran² \\ ${ }^{1}$ Senior Registrar, Madras ENT Research Foundation, Chennai \\ ${ }^{2}$ Consultant ENT Surgeon, Madras ENT Research Foundation, Chennai
}

Corresponding author: Ashish Alappatt, Department of Implantation Otology, Madras ENT Research Foundation, Raja Annamalaipuram, Chennai - 600 028, Tamil Nadu, India, Mobile: +919562261477 , Ph: +91 4424311411 / 412 / 413 / 414 / 415, Fax: +91 4424311 416, e-mail: dr_johnalappatt@yahoo.co.in

\section{Abstract}

Background: Candidacy for cochlear implantation has been expanding in recent times to include individuals with low-frequency residual hearing who do not benefit from conventional hearing amplification. Recent cochlear implant electrode arrays provide maximal preservation of residual hearing when introduced using a 'soft insertion' technique. This study analyzes the efficacy of soft insertion and the outcomes of such implantation in candidates with residual hearing.

Materials and Methods: Our prospective, non-randomized study, chronologically documented: (A) the efficacy of the hearing preservation technique in cochlear implantees with residual hearing by soft insertion technique (round window or cochleostomy), and (B) the auditory verbal outcomes in 10 cochlear implantees with residual hearing (Group A) compared with a control group of 10 age-matched post-lingual candidates with profound hearing loss (Group B), as measured by Categories of Auditory Performance, Speech Intelligibility Rating, Cochlear Implant Aided Audiometry, and Hearing In Noise Test.

Results: The results suggest that soft insertion via cochleostomy or round window were effective in preserving residual hearing. In the 6-month post-operative audiogram, $60 \%$ of our implantees had complete preservation and $40 \%$ had moderate preservation. Our study also underlines the beneficial effects of residual hearing: (a) hearing in noise test with mean average for Group A (59\%) and Group B (45\%) with $p$ value $=0.007$, (b) 6-month post-operative CI aided frequency specific comparison between the groups showed $p$ values of $0.001,0.039$, and 0.34 at 250,500 , and $1000 \mathrm{~Hz}$ respectively. However, on auditory verbal scores (CAP and SIR scores), Group A implantees performed better on clinical analysis, although there was no statistical significance.

Conclusions: The hearing preservation technique has heralded the arrival of next generation cochlear implants which provide a hearing solution for candidates with low-frequency residual hearing who do not benefit from conventional hearing aids. Our study shows that there is significant advantage obtained in auditory verbal habilitation outcomes and hearing in noise perception using soft surgery techniques which maintain the microstructure of the spiral ganglion and osseous spiral lamina.

Keywords: hearing preservation technique $\bullet$ ski slope audiogram $\bullet$ flexSOFT electrode $\bullet$ soft insertion technique $\bullet$ partial deafness cochlear implantation

\section{EFECTIVIDAD Y RESULTADOS DE LA TÉCNICA QUIRÚRGICA DE CONSERVACIÓN DEL OÍDO EN PACIENTES CON RESTOS AUDITIVOS AL COLOCAR UN IMPLANTE COCLEAR: EXPERIENCIA CON PACIENTES INDIOS}

\section{Resumen}

Introducción: Los criterios de calificación para un implante coclear se han ampliado en los últimos años y actualmente comprenden también a personas con restos auditivos en la zona de bajas frecuencias, pero que no obtienen ningún beneficio del uso de audífonos convencionales. Los tipos de electrodos para implantes cocleares más modernos permiten conservar al máximo los restos auditivos cuando se introducen en la cóclea utilizando una técnica de inserción suave del electrodo. En los estudios realizados se analizó la efectividad de la técnica de inserción suave del electrodo y el resultado de la colocación del electrodo utilizando esta técnica en candidatos con restos auditivos.

Material y métodos: Estudio prospectivo, no randomizado, documentado cronológicamente: (A) efectividad de la conservación del oído en pacientes implantados con restos auditivos utilizando la técnica de inserción suave del electrodo (por la ventana redonda o con cocleostomía), y (B) resultados auditivos y del habla de 10 pacientes con implantes cocleares que conservan 
restos auditivos (Grupo A), en comparación con el grupo de control, de edad similar, compuesto por 10 personas con sordera postlingual e hipoacusia profunda (Grupo B), examinados usando las categorías de rendimiento auditivo (Categories of Auditory Performance CAP), la evaluación de la inteligibilidad del habla (SIR), la audiometría asistida con implantes cocleares y los estudios de audición en ruido.

Resultados: Los resultados obtenidos permiten opinar que la técnica de inserción suave del electrodo con cocleostomía o por ventana redonda permite conservar con efectividad los restos auditivos. En el estudio audiométrico realizado 6 meses después de colocar el implante, se constató en el $60 \%$ de los pacientes implantados una conservación total del oído y en el $40 \%$ una conservación moderada del oído. Los resultados del estudio subrayan también los beneficios que ofrecen los restos auditivos: (a) el resultado medio de la prueba de audición en ruido para el grupo A (69\%) y el grupo B (45\%) con p=0,007, (b) la comparación de los resultados de la audiometría asistida con implantes cocleares realizada 6 meses después de la operación entre los grupos para frecuencias particulares dio un valor de p 0,001, 0,039 y 0,34 para 250, 500 y $1000 \mathrm{~Hz}$ respectivamente. Sin embargo, en las pruebas de inteligibilidad del habla (CAP y SIR) los resultados de los pacientes implantados del grupo A fueron mejores en el análisis clínico, aunque la diferencia no fue estadísticamente significativa.

Conclusiones: La técnica de conservación del oído anunció la llegada de una nueva generación de implantes cocleares destinados a pacientes con restos auditivos en la zona de bajas frecuencias que no obtenían beneficios del uso de audífonos convencionales. Nuestros estudios muestran que los pacientes obtienen resultados bastante mejores en la rehabilitación del oído y el habla y la audición en ruido si, al colocar el implante coclear, se utiliza la técnica de inserción suave del electrodo, que conserva la microestructura del ganglio espiral coclear y la lámina espiral ósea.

Palabras clave: técnica de conservación del oído • audiograma tipo 'ski slope’ • electrodo flexSOFT • técnica de inserción suave del electrodo $\bullet$ implante coclear en sordera parcial

\section{ЭФФЕКТИВНОСТЬ И РЕЗУЛЬТАТЫ ХИРУРГИЧЕСКОЙ ТЕХНИКИ СОХРАНЕНИЯ СЛУХА У ПАЦИЕНТОВ С ОСТАТКАМИ СЛУХА ПРИ ВЖИВЛЕНИИ УЛИТКОВОГО ИМПЛАНТАТА: ОПЫТ У ИНДИЙСКИХ ПАЦИЕНТОВ}

\section{Изложение}

Введение: Критерии допуска к вживлению улиткового имплантата в последние годы были расширены и сейчас они охватывают также людей, имеющих остатки слуха в пределах низких частот, но не имеющих пользы от пользования традиционными слуховыми аппаратами. Новейшие виды электродов улитковых имплантатов дают возможность максимального сохранения остатков слуха, когда они вводятся в улитку с использованием техники деликатного введения электрода. В проведенных исследованиях анализирована эффективность техники деликатного введения электрода и результата вживления электрода с использованием этой техники у кандидатов с остатками слуха.

Материал и методу: Проспективные, нерандомизированные, документированные хронологически исследования: (А) эффективность сохранения слуха у пациентов с остатками слуха, имплантированных с использованием техники деликатного введения электрода (путем круглого окна или кохлеостомии), (Б) результаты слуха и речи у 10 пациентов, пользующихся улитковыми имплантатами, имеющих сохраненные остатки слуха (Группа А) в сравнении с контрольной группой, подобранной по возрасту, состоящей из 10 постлингвально оглохших людей с глубокой тугоухостью (Группа Б), проверенных с использованием тестов категорий слуховых результатов (Categories of Auditory Performance CAP), оценки понимания речи (SIR), аудиометрии при поддержке улиткового имплантата и исследования слышания в шуме.

Результаты: Полученные результаты позволяют судить о том, что техника деликатного введения электрода путем кохлеостомии или круглого окна дает возможность эффективного сохранения остатков слуха. В аудиометрическом исследовании, проведенном через 6 месяцев после вживления имплантата у 60\% имплантированных пациентов обнаружено полное сохранение слуха, а у $40 \%$ - умеренное сохранение слуха. Результаты исследования подчеркивают также пользу, которую дают остатки слуха: а) средний результат теста слышания в шуме для группы А (69\%) и группы (Б) (45\%) при p=0,007, (6) сравнение результатов аудиометрии при поддержке улиткового имплантата, проведенной через 6 месяцев после операции между группами для отдельных частот дало значения р 0,001, 0,039 и 0,34 соответственно для 250, 500 и 1000 Гц. Однако в тестах понимания речи (САР и SIR) результаты имплантированных пациентов из группы А были лучше в клиническом анализе, хотя разница не была статистически значимой.

Итоги: Техника сохранения слуха была предвестником наступления новой генерации улитковых имплантатов, предназначенных для пациентов с остатками слуха в пределах низких частот, не имеющих пользы от пользования 
традиционными слуховыми аппаратами. Наши исследования показывают, что пациенты получают значительно лучшие результаты реабилитации слуха, речи и слышания в шуме, если при вживлении улиткового иплантата была использована техника деликатного введения электрода, сохраняющая микроструктуру улиткового протока и костной спиральной пластинки.

Ключевые слова: техника сохранения слуха • аудиограмма типа «ski slope» • электрод «flexSOFT electrode» • техника деликатного введения электрода • вживление улиткового имплантата при частичной глухоте

\section{SKUTECZNOŚĆ I WYNIKI TECHNIKI CHIRURGICZNEJ ZACHOWANIA SŁUCHU U PACJENTÓW Z RESZTKAMI SŁUCHOWYMI PRZY WSZCZEPIENIU IMPLANTU ŚLIMAKOWEGO: DOŚWIADCZENIE U PACJENTÓW INDYJSKICH}

\section{Streszczenie}

Wprowadzenie: Kryteria kwalifikacji do wszczepienia implantu ślimakowego w ostatnich latach były poszerzane i obecnie obejmują także osoby posiadające resztki słuchowe w obszarze niskich częstotliwości, ale nie odnoszące korzyści z zastosowania konwencjonalnych aparatów słuchowych. Najnowsze typy elektrod implantów ślimakowych umożliwiają maksymalne zachowanie resztek słuchowych gdy są wprowadzone do ślimaka z zastosowaniem techniki delikatnego włożenia elektrody. W przeprowadzonych badaniach analizowano skuteczność techniki delikatnego włożenia elektrody i wyniku wszczepienia elektrody z zastosowaniem tej techniki u kandydatów z resztkami słuchowymi.

Materiały i metody: Badanie prospektywne, nie randomizowane, udokumentowane chronologicznie: (A) skuteczność zachowania słuchu u pacjentów z resztkami słuchowymi implantowanych z zastosowaniem techniki delikatnego włożenia elektrody (przez okienko okrągłe lub kochleostomię), i (B) wyniki słuchowe i mowy 10 pacjentów korzystających z implantów ślimakowych posiadających zachowane resztki słuchowe (Grupa A) w porównaniu z grupą kontrolną, dopasowaną pod względem wieku, złożoną z 10 osób postlingwalnie ogłuchłych z głębokim niedosłuchem (Grupa B), zbadanych z użyciem testów kategorii wyników słuchowych (Categories of Auditory Performance CAP), oceny rozumienia mowy (SIR), audiometrii przy wspomaganiu implantem ślimakowym i badania słyszenia w szumie.

Wyniki: Uzyskane wyniki pozwalają sądzić, że technika delikatnego włożenia elektrody przez kochleostomię lub okienko okrągłe umożliwia skuteczne zachowanie resztek słuchowych. W badaniu audiometrycznym wykonanym 6 miesięcy po wszczepieniu implantu u 60\% pacjentów implantowanych stwierdzono całkowite zachowanie słuchu, a u $40 \%$ umiarkowane zachowanie słuchu. Wyniki badania podkreślają też korzyści, jakie dają resztki słuchowe: (a) średni wynik testu słyszenia w hałasie dla grupy A (69\%) i grupy B (45\%) przy p=0,007, (b) porównanie wyników audiometrii przy wspomaganiu implantem ślimakowym wykonanej 6 miesięcy po operacji między grupami dla poszczególnych częstotliwości dało wartości p 0,001, 0,039 i 0,34 dla odpowiednio 250, 500 i $1000 \mathrm{~Hz}$. Jednak w testach rozumienia mowy (CAP i SIR) wyniki pacjentów implantowanych z grupy A były lepsze w analizie klinicznej, chociaż różnica nie była statystycznie istotna.

Wnioski: Technika zachowania słuchu była zwiastunem nadejścia nowej generacji implantów ślimakowych, przeznaczonych dla pacjentów z resztkami słuchowymi w zakresie niskich częstotliwości nie odnoszących korzyści z zastosowania konwencjonalnych aparatów słuchowych. Nasze badania pokazują, że pacjenci uzyskują znacznie lepsze wyniki rehabilitacji słuchu i mowy i słyszenia w szumie, jeżeli przy wszczepieniu implantu ślimakowego zastosowana została technika delikatnego wszczepienia elektrody zachowująca mikrostrukturę zwoju ślimakowego i spiralnej blaszki kostnej.

Słowa kluczowe: technika zachowania słuchu • audiogram typu 'ski slope' • elektroda flexSOFT electrode • technika delikatnego włożenia elektrody • wszczepienie implantu ślimakowego w częściowej głuchocie

\section{Background}

Cochlear implants (CIs) have revolutionized the treatment of severe to profound sensorineural deafness. Candidacy for cochlear implantation has been expanding in recent times. Advances in speech processing strategies and implant design have significantly improved the performance of implant users. In recent times, candidates with poor word recognition abilities, good non-progressive low-frequency hearing, and poor high-frequency hearing have been included for cochlear implantation. Such patients with severe to profound high-frequency hearing loss above $1000 \mathrm{~Hz}$ and relative preservation of low-frequency hearing most often do poorly, even with bilateral conventional amplification.

In the past, these patients were not implanted due to the potential for additional hearing loss (i.e., loss of residual hearing) through trauma sustained during deep electrode insertion. Success has been achieved with the advent of hearing preservation techniques for conserving residual hearing after cochlear implantation. This has lead to improved word understanding and low-frequency speech recognition in these implantees $[1,2]$. It also allows the possibility of combining electrical and acoustic stimulation in the same ear (hybrid hearing). Studies have shown 

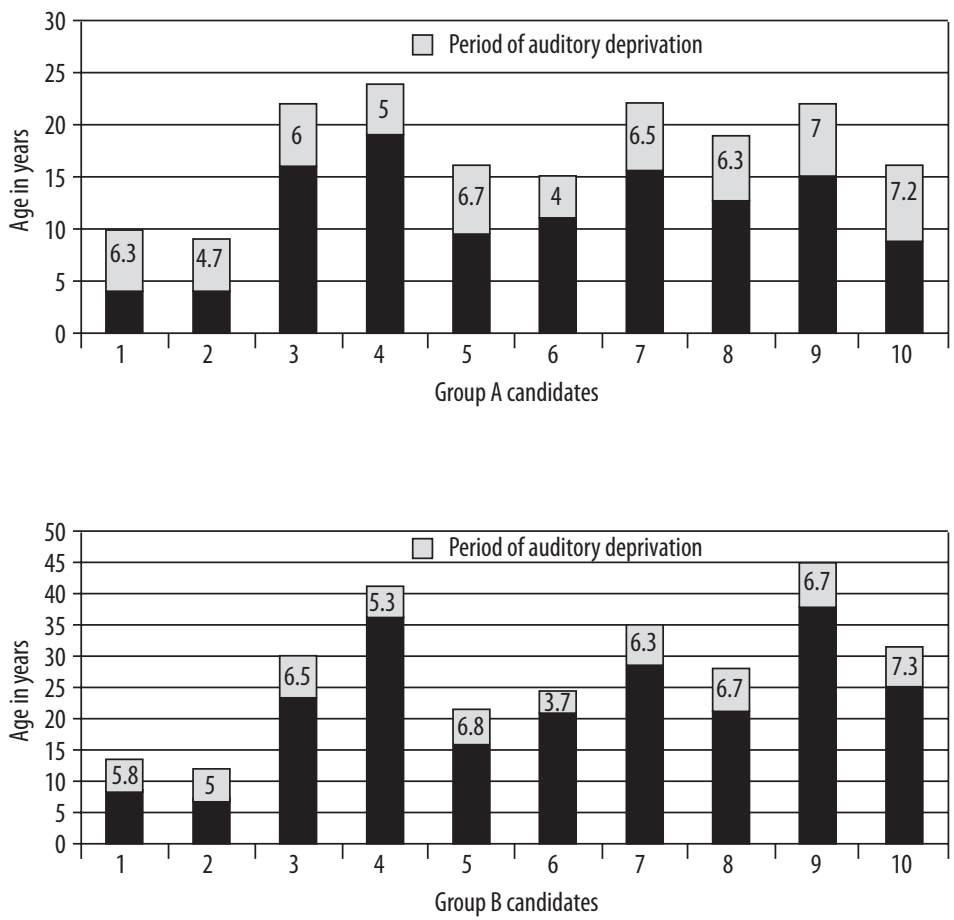

Figure 1. Age and period of auditory deprivation of Group A candidates

Figure 2. Age and period of auditory deprivation of Group B candidates that hybrid recipients are significantly more accurate than conventional CI recipients in recognising real-world songs without lyrics, which requires reliance on musical cues only [3]. This suggests that preservation of low-frequency acoustic hearing is important for perception of musical stimuli.

Our prospective, non-randomized study aimed to chronologically document: (A) the efficacy of hearing preservation techniques in cochlear implantees with residual hearing who received implants by the soft insertion technique (round window or cochleostomy), and (B) hearing outcome measures in cochlear implantees with residual hearing when compared with a control group of age-matched post-lingual candidates with severe to profound hearing loss, using standard scores of Categories of Auditory Performance (CAP), Speech Intelligibility Rating (SIR), CI Aided Audiometry, and Hearing In Noise Test (HINT).

\section{Material and Methods}

A consecutive series of post-lingual candidates aged 9-45 years were chosen during the period between February 2010 and January 2013 (36 months) to undergo cochlear implantation using the hearing preservation technique and a Pulsar flexSOFT electrode and Opus II processor (Med-El Corp., Innsbruck, Austria).

Group A comprised 10 candidates with audiometrically documented bilateral non-progressive hearing loss with residual hearing of less than $60 \mathrm{~dB}$ loss at $250 \mathrm{~Hz}$ and $500 \mathrm{~Hz}$, and more than $60 \mathrm{~dB}$ loss at $1 \mathrm{kHz}$ and beyond (ski slope audiogram), with mean age of 17.5 years and mean duration of auditory deprivation of $6 \pm 1.1$ years (SD) (Figure 1) and mean duration of auditory habilitation with a hearing aid of $2 \pm 0.6$ years. We excluded candidates with pre- and peri-lingual hearing loss, progressive hearing loss, syndromic association, autistic spectrum, demyelinating disease, central auditory processing disorders, and anomalies of inner ear and ossification of the cochlea. Group A underwent hearing preservation technique using 3 cochleostomies and 7 round window approaches as per the surgical indications.

Group B comprised 10 age-matched post-lingual candidates with severe to profound hearing loss and no residual hearing with mean age of 28.3 years and mean duration of auditory deprivation of $6 \pm 1.1$ yrs (Figure 2), fulfilling the criteria for cochlear implantation as per standard guidelines. The matching protocol was based on duration of auditory deprivation. All the candidates were counseled in detail about the study and informed consent was obtained. Institutional ethical review board clearance was given.

\section{Hearing preservation technique}

Cochlear implantation surgery was done by making a lazy ' $S$ ' shaped incision and raising an anteriorly based Palva flap. Cortical mastoidectomy and posterior tympanotomy was done to expose the round window niche. The position for the drilling of the well was identified, usually 2 $\mathrm{cm}$ posterior and superior to the mastoidectomy site. Prior to opening of cochlea, a single intravenous dose of methyl prednisolone [4] $(10 \mathrm{mg} / \mathrm{kg}$ body weight, max dose $500 \mathrm{mg}$ ) was given. The CI within the well was secured and tied down, keeping the knots away from the center.

The recommendations for cochleostomy size given by a number of different CI manufacturers vary. Regardless of the type of implant, we used a small cochleostomy [4], which was performed $1 \mathrm{~mm}$ inferior $[5,6]$ to the round window niche in the anterior aspect. This was performed 
Table 1. Group A unaided thresholds: comparison of pre- and 6 months post-op

\begin{tabular}{|c|c|c|c|c|c|c|c|c|c|c|c|}
\hline & ent & 1 & 2 & 3 & 4 & 5 & 6 & 7 & 8 & 9 & 10 \\
\hline \multirow{3}{*}{ Pre-op } & $250 \mathrm{~Hz}$ & 20 & 55 & 10 & 30 & 40 & 30 & 35 & 40 & 35 & 30 \\
\hline & $500 \mathrm{~Hz}$ & 30 & 60 & 25 & 55 & 60 & 50 & 60 & 55 & 55 & 50 \\
\hline & $1000 \mathrm{~Hz}$ & 70 & 80 & 70 & 70 & 85 & 70 & 70 & 65 & 70 & 70 \\
\hline \multirow{3}{*}{$\begin{array}{l}\text { Post-op } \\
\text { unaided }\end{array}$} & $250 \mathrm{~Hz}$ & 20 & 55 & 10 & 30 & 60 & 30 & 55 & 50 & 45 & 30 \\
\hline & $500 \mathrm{~Hz}$ & 30 & 60 & 25 & 55 & 80 & 50 & 80 & 70 & 60 & 50 \\
\hline & $1000 \mathrm{~Hz}$ & 70 & 80 & 70 & 70 & 90 & 70 & 85 & 85 & 80 & 70 \\
\hline \multicolumn{2}{|c|}{ Approach } & RW & $\mathrm{CH}$ & RW & RW & RW & RW & $\mathrm{CH}$ & RW & $\mathrm{CH}$ & RW \\
\hline
\end{tabular}

RW - round window; $\mathrm{CH}$ - cochleostomy.

with a $1-\mathrm{mm}$ diamond drill (Medtronic Xomed Skeeter). The endosteum was opened with a 0.2 -mm stapes pick. The smallest cochleostomy needed to insert the implant was used $(0.5-0.7 \mathrm{~mm})$. Suctioning of perilymph was avoided.

In the round window approach [7], the bony overhang was drilled and the round window membrane exposed. Just prior to insertion, an incision was made at the lateral part of the membrane in its antero-inferior quadrant.

Thereafter, the electrode array was inserted along the outer wall of the basal turn of the cochlea in an antero-inferior direction with the help of forceps (Advance Off-Stylet). All insertions were stopped at the point of first resistance to minimize cochlear trauma. The time between opening the cochlea and insertion was kept to minimum. The electrode array was stabilized and the site sealed with a small temporalis fascia graft [8] and fibrin glue. Insertion of the electrode was slow $(30-45 \mathrm{sec})$ to minimize intracochlear trauma [9]. Intravenous antibiotics were given peri- and post-operatively. All patients had uneventful surgery and post-operative period.

Switch-on was done in both groups as per the standard protocol. Pure tone audiogram (unaided) was done preoperatively and at 6 months post-operatively in group A to document the efficacy of hearing preservation. To assess the outcomes of the hearing preservation technique, a comparative analysis of CI aided audiogram, CAP scores, SIR scores, and HINT were done between the two groups after 6 months of surgery using Student's $t$-test.

Post-operative grading of hearing preservation [10] (Brown et al. 2010) was done using the following criteria. Complete preservation $\leq 10 \mathrm{~dB}$, moderate $11-20 \mathrm{~dB}$, marginal preservation $21-40 \mathrm{~dB}$, no preservation $>40 \mathrm{~dB}$.

\section{Results}

\section{A. Analysis of efficacy of hearing preservation} techniques

Surgical techniques of hearing preservation were successful in the study group as there was no statistically significant difference in residual hearing between preoperative values (Table 1) and postoperative values at 6 months ( $p$ value of
Table 2. Difference in hearing thresholds pre-op and 6 months post-op

\begin{tabular}{ccccc}
\hline Patient & $\mathbf{2 5 0 ~ H z}$ & $\mathbf{5 0 0 ~ H z}$ & $\mathbf{1 0 0 0 ~} \mathbf{~ z}$ & $\begin{array}{c}\text { Grade of } \\
\text { preservation }\end{array}$ \\
\hline 1 & 0 & 0 & 0 & Complete \\
\hline 2 & 0 & 0 & 0 & Complete \\
\hline 3 & 0 & 0 & 0 & Complete \\
\hline 4 & 0 & 0 & 0 & Complete \\
\hline 5 & 20 & 20 & 5 & Moderate \\
\hline 6 & 0 & 0 & 0 & Complete \\
\hline 7 & 20 & 20 & 15 & Moderate \\
\hline 8 & 10 & 15 & 20 & Moderate \\
\hline 10 & 10 & 5 & 10 & Moderate \\
\hline
\end{tabular}

0.051 at $250 \mathrm{~Hz}, p$ value of 0.058 at $500 \mathrm{~Hz}$, and $p$ value of 0.063 at $1000 \mathrm{~Hz}$ ) using a paired sample $t$-test.

As per the criteria for grading the preservation of residual hearing, 6 of the 10 candidates had complete preservation of residual hearing while 4 had moderate preservation of residual hearing at the end of 6 months postoperatively (Table 2).

\section{B. Analysis of outcome measures}

The CI aided pure tone thresholds between Group A and Group B at 6 months postoperative were compared separately in three frequencies using an independent sample $t$ test (Table 3). The $p$ values at 250,500 , and $1000 \mathrm{~Hz}$ were $0.001,0.039$, and 0.34 respectively.

A statistical analysis of Category of Auditory Performance (CAP) scores [11] between Group A and Group B was done at 6 months postoperatively (Figure 3). The mean average of CAP scores in Group A was 4.9, whereas for implantees in Group B it was 4.3. Even though Group A implantees performed better on a clinical analysis, there 
Table 3. Temporal analysis between Groups A and B ( 6 month aided audiogram)

\begin{tabular}{|c|c|c|c|c|c|c|}
\hline \multirow{2}{*}{ Patient } & \multicolumn{3}{|c|}{ Group A } & \multicolumn{3}{|c|}{ Group B } \\
\hline & $250 \mathrm{~Hz}$ & $500 \mathrm{~Hz}$ & $1000 \mathrm{~Hz}$ & $250 \mathrm{~Hz}$ & $500 \mathrm{~Hz}$ & $1000 \mathrm{~Hz}$ \\
\hline 1 & 20 & 20 & 40 & 30 & 50 & 50 \\
\hline 2 & 20 & 30 & 35 & 40 & 50 & 45 \\
\hline 3 & 10 & 20 & 30 & 35 & 45 & 45 \\
\hline 4 & 20 & 35 & 40 & 40 & 40 & 35 \\
\hline 5 & 40 & 55 & 60 & 35 & 40 & 35 \\
\hline 6 & 20 & 25 & 35 & 40 & 35 & 30 \\
\hline 7 & 30 & 30 & 40 & 40 & 30 & 30 \\
\hline 8 & 20 & 25 & 30 & 45 & 30 & 30 \\
\hline 9 & 35 & 40 & 55 & 55 & 40 & 40 \\
\hline 10 & 35 & 30 & 55 & 40 & 50 & 40 \\
\hline
\end{tabular}

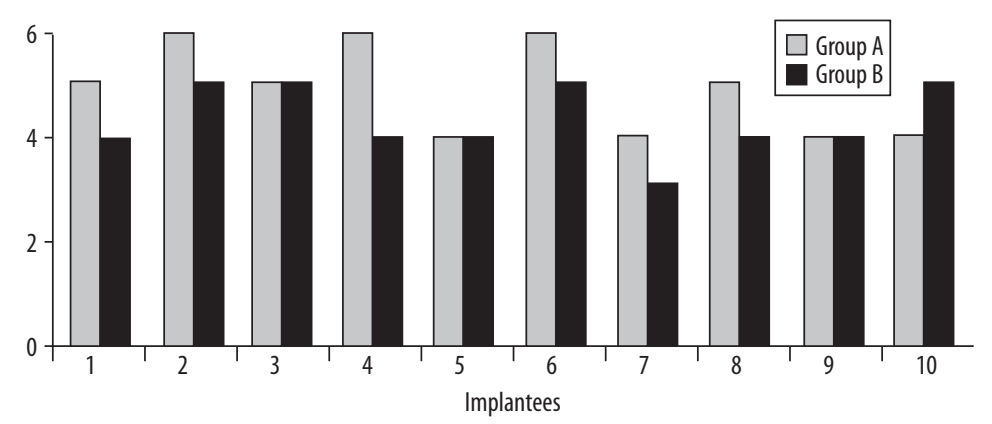

Figure 3. Comparison of category of auditory performance scores

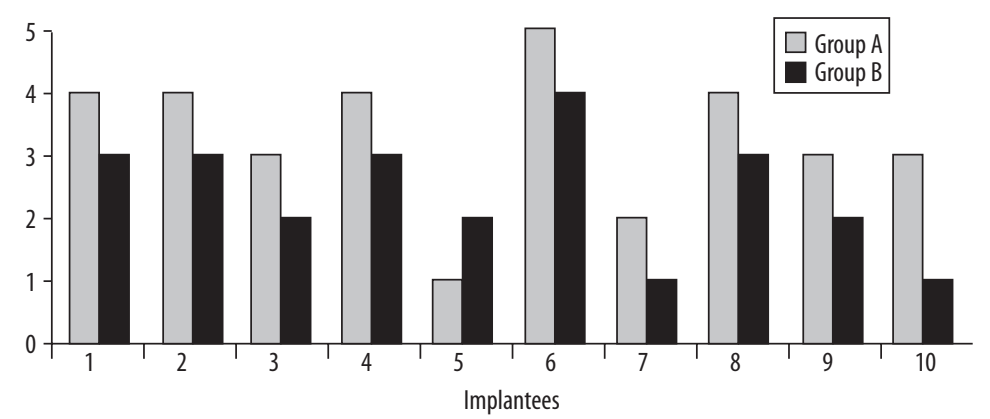

Figure 4. Comparison of speech intelligibility rating scores

was no statistically significant difference ( $p$ value 0.103 ) between the two groups.

A comparative evaluation of Speech Intelligibility Rating (SIR) scores [11] between Group A and Group B was done at 6 months postoperatively (Figure 4 ). The mean average of SIR scores in Group A was 3.3 and in Group B 2.4. A similar result was obtained as there was no statistically significant difference ( $p$ value 0.075 ) between the two groups.

An evaluation of the Hearing In Noise Test (HINT) was done 6 months postoperatively (Figure 5). The mean average for Group A was 59\% and for Group B 45\%. Statistically significant results were obtained ( $p$ value $=0.007$ ), indicative of better word understanding in noise in implantees with residual hearing compared to profound loss implantees. A possible rationale could be that surviving neurons at the residual hearing frequency contribute to better hearing in noise.

\section{Discussion}

In our study we have shown that there is good efficacy in preservation of residual hearing (6 candidates had complete preservation while the remaining 4 had moderate preservation) with soft surgery techniques via the round window or the cochleostomy approach [6]. Skarzynski et al. [7] in their large case series have shown that preservation 


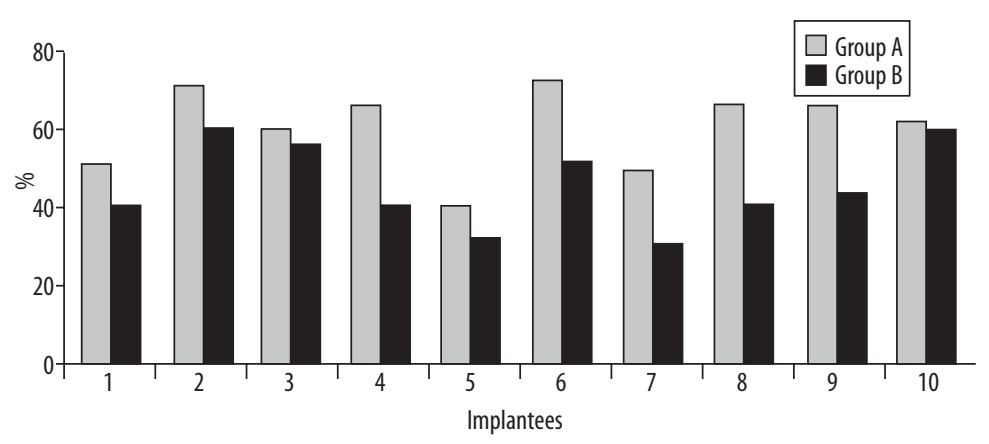

Figure 5. Comparison of hearing in noise test (HINT)

of low frequency hearing in partial deafness cochlear implantation (PDCI) is successful using the round window surgical approach. This earlier work has led to a conceptual change in electrode insertion, and this 'soft surgery' technique was followed in our study.

A comparative analysis of frequency specific CI aided audiograms between the two groups showed a statistical significant difference at 250 and $500 \mathrm{~Hz}$, with $1 \mathrm{kHz}$ being more modest. The possible reason is that there is less insertional trauma at $250 \mathrm{~Hz}$ and $500 \mathrm{~Hz}$ than at $1000 \mathrm{~Hz}$, which favors hearing preservation. We found that the CAP and SIR scores were comparable between the groups, being better in Group A, even though they were not statistically significant. A larger study is underway looking at longer outcomes in order to assess benefits among PDCI over time.

Our Group A candidates received only electrical stimulation at all frequencies and have shown to have equal or better auditory perception skills than their age-matched Group B candidates. The possible explanation is that with the minimal insertion trauma, there is a larger number of surviving neurons in regions of the cochlea with residual hearing [12] and electrical stimulation promotes the reorganization of the surviving neuronal population around the electrode array, thus facilitating better conduction of electrical impulses via the implant. A study done by Lorens [13] showed that patients with high levels of residual hearing (PDCI levels) receive benefits from cochlear implantation that are at least as good as the benefits received by patients with no residual hearing, with the majority of PDCI patients benefitting greatly.

The successful preservation of residual hearing after implantation can be considered a benchmark for atraumatic implantation $[8,14]$. Meticulous surgical techniques improve the chances of preserving functional ultrastructures, preventing neural degeneration and subsequent inflammatory reactions. Our Group A candidates had preservation of high levels of low-frequency acoustic hearing levels, e.g. $20 \mathrm{~dB}$ at $250 \mathrm{~Hz}$ in some of the candidates. These soft surgical techniques have opened the way to simultaneous electric and acoustic stimulation of the cochlea, and this combination has been shown to have not just additive but synergistic effects on auditory verbal measures [15], hearing in noise, and music perception.

In India, evaluation of outcomes in candidates with PDCI has evoked immense interest recently. Even though there is yet no documented research paper on preservation of residual hearing in Indian implantees, various centers across India have shown, based on preliminary clinical evidence, that the hearing preservation technique is beneficial for achieving better auditory verbal outcomes. A multicentric study is underway to document the long term outcomes and efficacy of preservation of residual hearing in India.

\section{Conclusions}

This study is the first of its kind in South Asia and our results document the outcomes in a group of Indian implantees. The hearing preservation technique has heralded the arrival of the next generation cochlear implants which provide a hearing solution for candidates with low-frequency residual hearing who do not benefit from conventional hearing aids. Our study shows that soft surgery techniques provide a significant advantage in auditory verbal habilitation outcomes and hearing in noise perception because they maintain the microstructure of the spiral ganglion and osseous spiral lamina.

Our study, part of an ongoing research program, allows us to makes inferences from a limited cohort of $10 \mathrm{im}$ plantees with residual hearing. A long-term evaluation of outcomes with a larger sample size is underway. Overall outcomes need to be further evaluated with multicentric studies. CI technology is further evolving to include electro acoustic stimulation (EAS) for pediatric population and bilateral EAS for binaural bimodal hearing.

Future research on hearing preservation in auditory pathways is being studied with advanced tools such as cortical auditory evoked potentials (CAEPs), positron emission tomography-computed tomography (PET-CT), near infrared spectroscopy (NIRS), as well as neural regeneration factors, stem cells, and drug delivery system have come into the purview of researchers and have been found to be successful in animal studies. Incorporation of these technological advances into present-day implant systems will enhance hearing preservation among cochlear implantees of the future.

\section{Acknowledgements}

Sincere thanks to the Department of Audiology, MERF Institute of Speech \& Hearing, Chennai, especially Mr Ranjith Rajeswaran, MSc (ASLP), and Ms Muthu Selvi T., MSc (Audiology), for helping us with all audiological investigations in this study. 


\section{References:}

1. Gantz BJ, Turner C, Gfeller KE, Lowder MW. Preservation of Hearing in Cochlear Implant Surgery: Advantages of Combined Electrical and Acoustical Speech Processing. The Laryngoscope, 2005; 115(5): 796-802.

2. Mowry SE, Woodson E, Gantz BJ. New frontiers in cochlear implantation: acoustic plus electric hearing, hearing preservation, and more. Otolaryngol Clin N Am, 2012; 45(1): 187-203.

3. Gfeller KE, Olszewski C, Turner C, Gantz B, Oleson J. Music perception with cochlear implants and residual hearing. Audiol Neurotol, 2006; 11 (Suppl.1): 12-15.

4. O'Connor EF, O'Connor AF. Hearing preservation surgery: current onions. Cochlear implants and hearing preservation. Adv Otorhinolaryngol, 2010; 67: 108-15.

5. Briggs RJ, Tykocinski M, Stidham K, Roberson JB. Cochleostomy site: implications for electrode placement and hearing preservation. Acta Otolaryngol, 2005; 125(8): 870-76.

6. Briggs RJ, Tykocinski M, Xu J, Risi F, Svehla M, Cowan R et al. Comparison of round window and cochleostomy approaches with a prototype hearing preservation electrode. Audiol Neurotol, 2006; 11 (Suppl.1): 42-48.

7. Skarzynski H, Lorens A, Piotrowska A, Anderson I. Preservation of low frequency hearing in partial deafness cochlear implantation (PDCI) using the round window surgical approach. Acta Otolaryngol, 2007; 127(1): 41-48.

8. Kiefer J, Gstoettner W, Baumgartner W, Pok SM, Tillein J, Ye $\mathrm{Q}$ et al. Conservation of low-frequency hearing in cochlear implantation. Acta Otolaryngol, 2004; 124(3): 272-80.
9. Kontorinis G, Lenarz T, Stöver T, Paasche G. Impact of the insertion speed of cochlear implant electrodes on the insertion forces. Otol Neurotol, 2011; 32(4): 565-50.

10. Brown RF, Hullar TE, Cadieux JH, Chole RA. Residual hearing preservation after pediatric cochlear implantation. Otol Neurotol, 2010; 31(8): 1221-26.

11. Nikolopoulos TP, O'Donoghue GM, Archbold S. The development of auditory perception in children following cochlear implantation. Int J Pediatr Otorhinolaryngol, 1999; 49 (Suppl.1): S189-91.

12. Leake PA, Stakhovskaya O, Hradek GT, Hetherington AM. Factors influencing neurotrophic effects of electrical stimulation in the deafened developing auditory system. Hear Res, 2008; 242(1-2): 86-99.

13. Lorens A, Polak M, Piotrowska A, Skarzynski H. Outcomes of treatment of partial deafness with cochlear implantation: a duet study. The Laryngoscope, 2008; 118(2): 288-94.

14. Adunka OF, Pillsbury HC, Kiefer J. Combining perimodiolar electrode placement and atraumatic insertion properties in cochlear implantation: fact or fantasy? Acta Otolaryngol, 2006; 126(5): 475-82.

15. Kiefer J, Pok M, Adunka O, Stürzebecher E, Baumgartner W, Schmidt $\mathrm{M}$ et al. Combined electric and acoustic stimulation of the auditory system: results of a clinical study. Audiol Neurotol, 2005; 10(3): 134-44. 